\title{
Reflections about the Spoken Language in Modern Romanian
}

\author{
Viorica Molea \\ Doctor of philological sciences, associate professor and the Faculty of Philology, Moldova State University \\ Chisinau, Republic of Moldova
}

*Corresponding Author: Viorica Molea, Doctor of philological sciences, associate professor and the Faculty of Philology, Moldova State University Chisinau, Republic of Moldova

\begin{abstract}
The spoken language has not always been a priority for linguists, as it is too dynamic and permissive, and the issues connected to its inner delimitations are complex, the boundaries being very "fragile" and even uncertain. For example, some researchers consider the spoken language as being colloquial, familiar or regional, whereas we distinguish two main aspects: standard and substandard spoken language, that both have well-defined features. In this article we try to delimit stylistically the spoken language from the written discourse, pointing out that, ultimately, the two stylistic (oral / written) registers are approaching more and more despite of the speakers' massive access to information, of the unprecedented diversification of the means of communication.
\end{abstract}

Keywords: spoken language, standard, substandard, official, colloquial, familiar, folk.

\section{STANDARD Vs SUBSTANDARD ORALITY}

The spoken language as a linguistic phenomenon is a key interest for most linguists who, in one way or another, are trying to get into the essence of this dimension of human communication by studying various aspects of language related to the history of language, dialectology, sociolinguistics, psycholinguistics, stylistics, communication, pragmatics, etc.

Depending on the purpose of communication and the situational context, we delimit the standard spoken language, which includes the institutional language, the oral discourse, which is related to rhetoric, and the substandard spoken language, with its stylistically labeled layers, grammatical deviations from the literary norm, which has a special status and is well delimited within the language structure. Thus, the spoken language has many aspects, that characterize, with a few exceptions, either its special particularities as a part of the modern Romanian language, or some distinct features, which are not in accordance with the basic linguistic norm. Both standard and substandard spoken languages have their own contexts of use, types of speakers and a specific extra-verbal context. Therefore, the neutral standard spoken language is usually used in public institutions, being mainly characterized as "official", "sober" or "neutral". At the same time, almost all the acting literary norms are respected at all levels: phonological, lexical and grammatical. The spoken language is used both in dialogues (administrative institutions, in discussions between heads and employees, employees and clients) and in monologues (predominantly in educational institutions (at lectures, conferences), in courts (judges' indictments, lawyers' pleadings), and in legislative and executive branches, etc.) as well. Ch. Bally does not regard this type of language as being part of the spoken language, such texts being called "authentic" and "non-authentic", so that the lecture and academic communication are not part of the oral form of the language, but of the written one ${ }^{[1]}$. The informal, neutral, standard, oral language is, in fact, the spoken language which has no connotations and is part of colloquial language. We mean that there are various communication situations, ranging from plain conversations to larger dialogues about the most common things: discussions about time, family household, unimportant but necessary situations in the working environment, etc. This type of spoken language, or "the spoken version of the standard language" as it was named by Margareta Manu Magda, "belongs to the non-specialized stylistic level, being differentiated (on the axis of a permissiveness scale $+/$ - acceptability in relation to the prescriptive norm) by formal characteristics, "colloquial" (semiformal), familiar (informal) ${ }^{[2]}$. Obviously, this classification of the spoken language seems rather artificial, but if we refer to the 
standard language, we can see that some of its aspects do not match this category, because "standard" implies, among other characteristics, the absence of affective elements.

On the other hand, we speak of substandard spoken language (or non-standard as it was named by Manu Magda), which is also highlighted by several defining features. The term " substandard," as mentioned earlier, was suggested by the researcher Klaus Bochmann, who defined it as "negative: as "not characteristic of the standard", which is named "uncodified" by Ammon, or "not stipulated by the official rules"; here it should be completed with "non prestigious" if referred to the whole territory of the state ... " ${ }^{[3]}$, with the meaning that it refers to its unofficial, informal status, but also to other elements of the spoken language that subordinate to the literary language. The researcher comes up with judicious arguments by explaining and justifying this terminology: "In fact, absolutely positive characteristics do not exist, but only" informal ", all others being delimited by the pattern "predominantly oral "(despite certain written word combinations) which is specific to lower social categories (but also used in the spoken language of higher social classes); "regional" (but tending to supra regional) ". [idem]

\section{Features of the Substandard Language: Dialect/Regional Language; Spoken ROMANIAN}

Most studies on substandard spoken language refer to the dialectal / regional language, which is the basis of the Romanian language from the historical and nowadays regions of our people. There have been elaborated linguistic atlases, which contain many writings collected from all the territories populated by the Romanians. Also, the spoken, or everyday Romanian has also been studied from various points of view, these studies are based on a solid, well-organized investigation of different texts which were collected and published in several volumes (Vulpe M., Margareta Manu Magda, Slama-Cazacu T. et al]. As a very large category, it contains several layers/verbal levels, characterized by some stylistic aspects such as affective, spontaneous, informal, etc. As we have mentioned, these layers represent essentially different verbal nuclei, which are not formed in existing lexical systems, but only in various stylistic registers, but penetrate somehow into the vocabulary of the Romanian language, in spite of their massive acceptance in the language usage. These nuclei are more like a kind elements, or verbal units than the proper spoken language, because they are used in various communication styles or are inserted into artistic or journalistic texts to give them stylistic coloring or special pragmatic values. They are language elements that oppose the literary language, fitting into the concept of spoken language with some characteristics of the folk language. M.Vulpe also considers them as folk elements: "We suggest that these elements, which are geographically spread, but not in accordance with the norms of the literary language, to be named folk elements. Within the social stratification of the language, they oppose literary elements. " ${ }^{[4]}$. In dictionaries, these vocabulary elements are graphically marked with the indication of the respective stylistic aspect. If we refer to the phonological and grammatical levels, to the verbal structures of this category of spoken language, we will discover that the phonetic aspect is mostly part of the regional language, but the syntactic aspect does not fit into the literary grammatical system of the Romanian language, being considered a deviation from the literary norm.

Therefore, all words which are marked stylistically with the general and valid sign "folk", enter this category. Although they are termed differently (regionalisms, slangs, barbarisms or vulgarisms, familiar words, jargons, etc.), they all are part of the "folk" or "familiar" concepts, as we have already mentioned. At the same time, we also include in this category the affective aspect of the spoken language, which can be found in emotive, unhindered, free from certain social and ethical conventions word combinations, etc. (e.g. various interjections, addresses, descriptions made as a result of strong feelings), which, in the ordinary, neutral dialogue, is not influenced by certain extra-verbal factors, as well as by various forms and expressive grammatical structures. As Manu Magda has noted "oral communication, being empathic and participatory, contains many types of affective elements characteristic of oral statements: interjections, words used to describe emotions, repetitions, exclamations, rhetorical interrogations, etc." ${ }^{[5]}$. So, "it is the case of our language, the folk language, the conversational (familiar) language, the current conversation, the standard language " ${ }^{[6]}$ as particular achievements of the common (spoken) Romanian. 


\section{Digital Orality: A Hybrid of Oral and Written language}

We can observe an innovative aspect of the category of spoken language, which involves both standard and substandard spoken language. As a result, a third form of communication is outlining, not quite vivid though, the so-called "digital- spoken language", which is mediated by the computer, which generally involves conjugation and a mixed form consisting of elements of spoken and written language. Here are included both aspects of the standard and substandard spoken language, resulting in an "oral written communication" according to the opinion of more researchers [R. Zafiu, E. Ungureanu, A. Moise, C. I. Mladin, I. Uruşciuc, M.-D. Grosseck, A. Negru, I. Pomian, M. Krongauz, A.V. Kuznetsov, C. A. Lysenko et al.]. Making reference to the chat and blog, I.Grosseck M.-D, Negru A. show the situation of the contemporary form of communication: " The chat has transformed the written communication into an oral one, but it uses the written language. This type of communication is described by linguists as a colloquial language which has become written for some technical reasons." ${ }^{[7]}$ However, we place it in the spoken language diagram because it is essentially oral, even if it uses some elements of the written form.

\section{DistinCtion BETWEen STANDARD AND SUbSTANDARD ORALITY}

We find, therefore, that the two types of spoken language differ according to the "standard" I "substandard" or "literary" / "non-literary" criterion. Here are some characteristics of the standard spoken language:

- Its basis is the general system of contemporary Romanian language at phonological, lexical and grammatical levels;

- It is characterized by stylistic homogeneity;

- It is emotionally neutral;

- It lacks aesthetic creativity, i.e. it does not contain various connotations;

- It has referential, conative and phatic functions;

- It is intentional, persuasive, objective;

- It is both dialogue and monologue;

- It is elaborated, but can also be spontaneous;

- It obeys the grammatical rules of the Romanian language.

\section{The Characteristics of Substandard Spoken Language are}

- It does not represent distinct linguistic systems, only functional-stylistic layers;

- It is characterized by stylistic heterogeneity;

- It is emotional, personalized;

- It is based on metaphorical creativity, it is connotative;

- It has the expressive or phatic function;

- It is intentional, persuasive, subjective;

- It manifests itself in dialogue and monologue;

- It is spontaneous, unprepared but also deliberate;

- It does not follow the rules of the contemporary literary language.

Some peculiarities of the substandard spoken language, which seemed relevant to us, have been taken over from the Russian linguistics, namely the lack of a system in substandard spoken language: "The substandard spoken language is not a part of the language system. It consists of separate expressive elements, which are used, through their insertion into the literary text, in order to give some lightness, familiarity, and sometimes vulgarity. The substandard spoken language is a "palette of colors." ${ }^{[8]}$. The folk language is, in fact, based on the general system of Romanian literary language. 


\section{OPINIONS ON SUBSTANDARD ORALITY}

Being a field of language acts which are not consistent with the literary norms, the substandard spoken language is used in both face-to-face communication and written literary texts. In this way, they enrich and reveal their reflexive-stylistic and pragmatic background.

Thus, we note that these two forms of language are mostly in opposition to each other, each of them has distinct features; however, we will highlight some common issues, which represent their basic condition - its oral form.

There exist several classifications and taxonomies of stylistic registers of the spoken language, which describe the distinctions, the differentiating characteristics, but also the specific aspects of each type of spoken language.

Since the "collocation" in the spoken language is general for both types of spoken language (both standard and substandard), we will bring some definitions which we consider relevant to understanding this concept in two ways. So, I. Ghetie, for instance, considers that "regarding the colloquial style, as it was defined by C. Maneca, there are some reasons for doubting its presence among the Romanian literary styles (a similar observation in relation to the familiar language)". ${ }^{[9]}$

Being predominantly classified as familiar or colloquial style in the classification of functional styles, we will show that these two types of spoken language also represent the defining marks for most of the spoken languages registers. Thus, the other types, categorized as parts of the spoken language, obey or overlap with these formulas revealed by the researchers. There are obviously some correspondences between all the verbal formulas of the spoken language, but there are also distinctive features expressed through a lot of notes and specific details to each separate type. The colloquial style, according to the studies, comprises the whole range of folkloric linguistic elements and is expressed by the basic features of the spoken language, such as: familiarity, affectivity, spontaneity and is characterized by the phatic, expressive, emotional and referential functions. Its definition involves taking into account the comprehensive, generalizing character of the spoken language.

We have come across several definitions of Colloquial Language in Spanish studies in linguistics. For example, W. Beinhauer (1985: 9) suggests that "colloquial language is natural and spontaneous as it is in daily conversation, unlike linguistic texts which are consciously formulated (...) or those artistically shaped by the writers, journalists or poets ...". The scholar also considers that, when it comes to colloquial language, we refer strictly to the lively, conversational language. [apud: 10] There is also another definition of the colloquial language proposed by Dámaso Alonso, which is "the ordinary Spanish language in most of the cases is not recorded anywhere and there is no reason for looking it up in dictionaries and grammars."[idem] G. Muşat notes that G. Alfaro considers that "Colloquial means an intimate conversation, a plain dialogue, which lacks individuality, in which words are spontaneous and not purposefully selected. [idem]

\section{Stylistic Markers and Connotations of Colloquial}

As we can see, the above-mentioned authors define the colloquial style as a live, ordinary speech without noticing its affective, connotative background. Or, we reveal just the stylistic aspects that involve emotional, attitudinal reactions: argots, jargons, regionalisms, diminutives, augmentatives, phraseological units, pejoratives, vulgar words, familiar words, invectives, onomatopoetic elements, etc. The listed features refer, in fact, to the colloquial-familiar style, and not to the neutral colloquial, which is closer to standard language. All these colloquial-familiar elements create the expressivestylistic layers of the spoken language, which were firstly mentioned by $\mathrm{Ch}$. Bally and then by I. Jordan: "... the spoken language is more spontaneous, more natural and free than the written language, therefore it is richer in words, formulas and expressive word combinations and emotive elements ". ${ }^{111]}$ When mentioning the affective aspect of language, E. Coşeriu notes that "when we speak, we also express emotions and react emotionally; and it can even be admitted the existence of an emotional compliance or "stylistic", of an "emotive" language which is different from the purely declarative language " ${ }^{[12]}$ The researcher refers, through the "existence of an emotional or" stylistic "compliance" to the peculiarities of the colloquial-familiar language, which has, first of all, an emotive function. We can evoke here the three types of variety, mentioned by the scientist, that have become recognized in general linguistics: "diatopic variety (in space), diastolic variety (between the social and cultural layers of a community) and diaphasic diversity (between the ways of speech which are 
determined by the situation itself, that is, who speaks, with whom, about what, under what circumstances) "[13].

\section{Folk LANGUAGE ENCAPSUlATING THE SUBSTANDARD LANGUAGE}

Thus, the colloquial style is characterized both by an ordinary language, stylistically neutral, which renders the daily speech, without emotional implications, and by some elements of language called "affection products" through metaphorical structures, through a rich system of stylistically-expressive elements which form the spontaneous, vivid and relaxed speech, with its lots of nuances and values, it being called the familiar or folkloric-familiar colloquial style. At the same time, we note that there is no strict demarcation between other terms, somehow confused with the colloquial and familiar ones, namely, with the terms "folk", "regional" and "spoken language", which makes their research difficult under various aspects. M. Vulpe notes that "The particularities listed as non-literary in grammar, dialectology and stylistic works are usually described as regional, folkloric or specific to the spoken language, but the authors do not always state the criteria used in classification. As the mentioned terms are not synonymous, it is necessary to give them a more precise definition.'[14]. This confusion of terms is caused by a greater freedom of spoken language use, which includes the aspects mentioned above, as opposed to written literary language. Thus, Manu Magda notes that, since oral communication is more permissive, some language elements "may belong to nonstandard registers of communication: folk language, argots or regional variations for which the oral use of language is specific". ${ }^{[15]}$

The one that is continuously used in all studies concerning the stylistic registers of the Romanian language is the folk language, the compartment that defines the substandard spoken language. Thus, the folk language is the one from which all non-standard, expressive, vulgar, argotic, regional, neological lexical elements derive. Ion Coteanu explicitly reveals that the folk language has a fundamental role for a language, it is the foundation of both the stylistic variants of the language and the cultivated, civilized language of a people. K. Bochkmann states that "the commonly used term of folk language is, after a closer consideration, only a collective concept for substandard varieties of regional origin specially" ${ }^{[16]}$ Cristina Florescu also understands the term "folk" as a generalizing one, stating that "the dissociation of the familiarity is not of a direct interest as long as the concept of folk in its broad sense is perfectly operative." ${ }^{[17]}$. Ion Coteanu considers the folk language a profound cultural surface, underlining that being "a fundamental variant of any idiom, the folk language first of all renders through its structure, a stage of culture and civilization." ${ }^{[18]}$, thus suggesting the aesthetic aspect of the folk spoken language. C. Milaş notes these evidences, stating that within the structure of the folk language "we can distinguish a variant used in the current conversation and an artistic variant used in oral folk arts." ${ }^{[19]}$. Moreover, Ion Coteanu divides the folk message into "two main categories: some are used in the current conversation, in the family and outside it, in the day-to-day conversations between the speakers; others have the purpose of expressing folk literature of imagination ...." ${ }^{[20]}$ Here we have to say that we are only discussing the first category announced by the great scholar, namely, the one that relates to" the current conversation in the family and outside it, in everyday relationships between the speakers. "

Some aspects related to the concept "folk" are also revealed in the "History of the Romanian Language" [21], stating that the concepts folk expressive means, folk phenomenon, folk element, peculiarity or folk feature, a phenomenon of a folk character "have been used either with the sense of a " non-literary spoken language act", or in the sense of a " non-elitist language act", being used in larger areas than regionalisms."[idem]. At the same time, the authors mention that there is no objective criterion that would indicate "the boundaries of a region where a concept is usually used, so that we could consider it a folk concept." [idem]

It is the folk language that unites all forms of substandard spoken language. The distinctive feature of folk language is the stylistic mark of the used verbal elements, i.e. the concept "folk" means "emotive, stylistically colored". In his study of the stylistic structure of the language, I. Coteanu considers the opposition "folk" language - literary "language" as the fundamental stylistic opposition ", notes M. Vulpe ${ }^{[22]}$. R. Zafiu regards the folk language as an "abstract concept, generalizing, defined by the characteristics of the spoken language, which are superior to the dialect. Being prominent for its richness and expressiveness, the folk language is in fact subjected to a very severe selection by the "high" culture, that reduces it to an idealized image ..." ${ }^{\text {[23] }}$. According to this thesis, the folk language 
acquires almost idyllic significance, rising above the condition of substandard language. In our opinion, this term does not necessarily mean regional, brutal or indecent. The concept "substandard" has the simple meaning of "nonstandard", that does not meet the standard. We can speak of various levels and types of expressivity of the spoken language. The folk language has a major hidden expressiveness, but this does not exclude it from the general category of the linguistic substandard. Thus, the folk language is seen in a broad sense by D. Irimia, who distinguishes two distinct variants in the stylistic structure of the Romanian language: the written version and the oral variant of the language. While describing them, D. Irimia determines the internal dynamics of this system as well as the relation between the two variants: "In its evolution, the internal dynamics of the stylistic system is oriented by the relation between the oral version of the language and the variant rendered in writing (which is shaped by writing), and the relationship between the folk language and the literary language within its expansion. ${ }^{[24]}$ For D. Irimia, folk language combines all aspects of the spoken language that do not belong to "literary", or "standard," i.e. all the elements of the substandard. But, we have to mention that the spoken variant of the language also comprises the standard literary section, which was later called "derivative spoken language" by the researcher D. Irimia ${ }^{[25]}$.

Tanu-Pohrib Iu. considers that the folk language "is composed of the words which are used in the environments and situations that are not influenced by the professional and cultural requirements." The researcher believes that these are primarily the rural environments and, to a large extent, suburban environments, from rural areas. Then, it is about "situations in which well-read speakers use the terms that are not included in the registers of the literary language." Thus, the author notes that "if for the first category of speakers, folk language is important, dominant, or even generalizing, for the second category, it is secondary and is sometimes called as the "spare register". ${ }^{[26]}$ However, it should be noted that at present, even if it is a slow process, the two categories of language speakers and registers interconnect more and more so that we can no longer speak of an absolute distinction between them. This fact is generated by the unprecedented access of all speakers to social, cultural, scientific, economic, etc. values, promoted through the media for the narrow interest of consumers and commercial interests. Almost any speaker knows the lexical elements that are neological or even bookish, which was impossible only a few decades ago. Some examples are the medical scientific terms: osteoporosis, cord, melanoma, atheroma etc; psychological terms: empathy, introvert, extrovert; economic: inflation, devaluation, gross, appreciation; terms related to culture: sketch, hit, showbiz; of fashion: trend, VIP etc. These are the most recent loan words, which mark the immediate sequence of the experience. Therefore, the evolution of this linguistic scenario is more than ever dictated by trivial, concrete facts related to the financial wellness and not to the spiritual life of man, in spite of the ordinary peoples' attempts to enrich their vocabulary, if compared with some centuries ago when such words were spread by educated individuals only. At the same time, these lexical elements do not have any connotations specific to the substandard spoken language, even though they are present in the current spoken language. On the other hand, the folk language is stylistically marked, its expressiveness being both inherited through its own form and expression, and acquired in revealing contexts.

The words, word combinations and structures, which are not stylistically colored, are neutral from the point of view of the language use; they are denotative, unemotional and are part of standard language forms. Therefore, the word "folk" means connotative, it represents a conjugation of all language manifestations and fits the national spirit of a language in evolution. That is why the folk language is mostly used in writings (both belle-lettres style and the journalistic style), where they are offered authenticity, originality, a genuine character and naturalness. Folk language is thus the expression of revealing verbal configurations, is a part of a separate existential projection, specific to a people and is the unique sacred essence of a nation.

\section{REFERENCES}

[1] Dolinin K., Stilistika francuzkogo jazyka. Leningrad: Prosveščenie, p. 275 (1978)

[2] Manu Magda M., GALR II 2008, Limba română vorbită. În Gramatica limbii române, II, Enunţul. [Spoken Romanian in „Academic Grammar of Romanian”, II, The Sentence.]. Bucharest: Publishing House of the Romanian Academy, Institute "Iorgu Iordan - Al. Rosetti”, p. 869 - 904, p. 869 (2008) 
[3] Bochmann K. Limba română: istorie, variante, conflicte, o privire din afară. [Romanian Language: History, variety, conflicts, an outside view]. Chișinău: Cartdidact (2004).

[4] Vulpe M. Opera lingvistică. Dialectal, popular, vorbit. [Linguistic Works. Dialectal, folk, spoken], Vol. I. Cluj-Napoca: Clusium, p. 62-63 (2004).

[5] Manu Magda M., GALR II 2008, Limba română vorbită. În Gramatica limbii române, II, Enunţul. [Spoken Romanian in „Academic Grammar of Romanian”, II, The Sentence.]. Bucharest: Publishing House of the Romani.an Academy, Institute of Linguistic “Iorgu Iordan - Al. Rosetti”, p. 869 - 904, p. 864 (2008)

[6] Vasiliu Em. Fonologia limbii române. [Fonology of Romanian] București, Editura Știinţifică, p. 19 (1965).

[7] Grosseck M.-D., Negru A. Chat-ul şi blog-ul - limbaje ale noii generaţii şi influenţa lor asupra comunicării. [Chats and blogs - languages of the new generations and it`s influence on communication]. Available online at: http://culturasicomunicare.com/pdf/2008/negru.pdf, accessed on 18.08.13.

[8] Zemskaja E. A., Kitajgorodskaja M. F.,. Širjaev E. N., Russkaja razgavornaja reč`. Obščie voprosy. [Spoken Russian: A general View]. Slovoobrazovanie, Moscow: Nauka, p. 52 (1981).

[9] Gheție I. Istoria limbii române literare. [History of standard Romanian]. Bucharest: Editura Științifică și Enciclopedică, p. 29 (1978).

[10] Muşat G. Spaniola colocvială - trăsături caracteristice. În: Limbajul colocvial în spațiul romanic. Studiu pragmalingvistic diacronic și sincronic. [Colloquial Spanish - special features in „Colloquial language in Romania Occidentalis. Diachronic and syncronic pragmalinguistic studies”]. Cermi, 2008. Coordonaor: Mirela AIOANE [online] http://en.calameo.com/read/000211391885eaa687849 last accessed on 27.10.2017

[11] Irimia D. Introducere în stilistică. [An introduction to stylistics] Iaşi: Polirom, p. 14-15 (1999).

[12] Coșeriu E. Introducere în lingvistică. [An introduction to linguistics]. Cluj: Ed. Echinox, p. 54 (1995).

[13] Coșeriu E. Prelegeri și conferințe. [Lectures and Talks]. "Alexandru Philippide” Institute of Romanian Philology. Iași: F.C. Dosoftei S. A., p. 38 (1994).

[14] Vulpe M. Opera lingvistică. Dialectal, popular, vorbit. [Linguistic Works. Dialectal, folk, spoken]. Vol. I. Cluj-Napoca: Clusium, p. 72 (2004).

[15] Manu Magda M., GALR II 2008, Limba română vorbită. În Gramatica limbii române, II, Enunţul. [Spoken Romanian in „Academic Grammar of Romanian”, II, The Sentence]. Bucharest: Publishing House of the Romani.an Academy, Institute of Linguistic "Iorgu Iordan - Al. Rosetti”, p. 869 - 904, p. 870 (2008)

[16] Bochmann K. Limba română: istorie, variante, conflicte, o privire din afară. [Romanian Language: History, variety, conflicts, an outside view]. Chişinău: Cartdidact, p. 152 (2004).

[17] Florescu C. Considerații cu privire la limbajul familiar românesc. [Consideration on familial Romanian language]. http://calliope22.files.wordpress.com/2011/03/limbajul-familial-romanesc.pdf Accessed on 27.10.2017.

[18] Coteanu I. Stilistica funcțională a limbii române. Stil, stilistică, limbaj. [Functional stylistics of Romanian. Style, stylistics, language]. Bucharest: Editura Academiei R.S.R., p. 91 (1973).

[19] Milaș C. Introducere în stilistica oralităţii. [An introduction to the stylistics of orality]. Bucharest: Editura Ştiinţifică şi Enciclopedică, 1988.

[20] Coteanu I. Stilistica funcțională a limbii române. Stil, stilistică, limbaj. [Functional stylistics of Romanian. Style, stylistics, language]. Bucharest: Editura Academiei R.S.R., p. 100 (1973).

[21] Rosetti Al., Cazacu B., Onu L. Istoria limbii române literare. [History of standard Romanian]. Bucharest: Editura Minerva, 116,179, 507, 510 (1971).

[22] Vulpe M. Opera lingvistică. Dialectal, popular, vorbit. [Linguistic Works. Dialectal, folk, spoken]. Vol. I. Cluj-Napoca: Clusium, p. 73 (2004).

[23] Zafiu Rodica Prestigiul oralităţii. Păcatele limbii. Revista România literară, nr. 47, 2001. [The Prestige of Orality. The sins of language]. Accessed on 27.10.2017 at http://www.romlit.ro/prestigiul_oralitii

[24] Irimia D. Structura stilistică a limbii române contemporane. [The stylistic Structure of contemporary Romanian]. Bucharest: Editura Ştiinţifică şi Enciclopedică, p. 244 (1986).

[25] Irimia D. Introducere în stilistică. [An introduction to stylistics] Iași: Polirom, p. 121 (1999).

[26] T, Tanu-Pohrib I. Limbajul tinerilor - argou/jargon. [The language of youngsters - argot/ slang]. Editura Sfântul Ierarh Nicolae, 2010. [online] Can be accessed online at http://bibliotecascolara.ro/Tanu_ Iuliana/Limbajul_tinerilor-argou_jargon.pdf 


\section{AUTHORS' BIOGRAPHY}

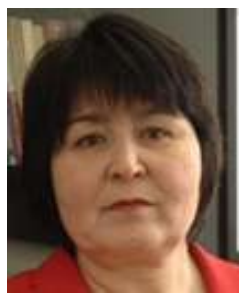

Viorica Molea, I am a PHD lecturer in the Romanian Linguistics and Science Department, Faculty of Letters of the State University of Moldova. I hold academic classes for both first and second-cycle academic degree. My scientific concerns relate to the following areas: stylistics, pragmatics, textual analysis, semiotics, etc. I have published three books: two monographs and a support course (Expressive Values of Idioms in the Dramatic Text; Orality in the Current Romanian Journalistic various journals and collective volumes of conferences and scientific symposiums.

Citation: Viorica, Molea. "Reflections about the Spoken Language in Modern Romanian." International Journal of Humanities Social Sciences and Education (IJHSSE), vol 4, no. 11, 2017, pp. 1-8. doi:http://dx.doi.org/10.20431/2349-0381.0411001.

Copyright: () 2017 Authors. This is an open-access article distributed under the terms of the Creative Commons Attribution License, which permits unrestricted use, distribution, and reproduction in any medium, provided the original author and source are credited. 